\title{
FAKTOR-FAKTOR YANG MEMPENGARUHI KINERJA PEGAWAI PADA BIDANG SUMBER DAYA AIR DINAS PEKERJAAN UMUM DAN PENATAAN RUANG PROVINSI BENGKULU
}

\author{
Nia Indriasari, Oni Yulianti, Herawati \\ Program Studi Manajemen Fakultas Ekonomi Universitas Dehasen Bengkulu \\ Indriasari_nia@yahoo.com
}

\begin{abstract}
ABSTRAK
Nia Indriasari, Oni Yulianti, Herawati; Tujuan penelitian ini adalah untuk mengetahui faktor yang dominan mempengaruhi kinerja pegawai pada Bidang Sumber Daya Air Dinas Pekerjaan Umum Dan Penataan Ruang Provinsi Bengkulu. Faktor yang paling dominan/tertinggi mempengaruhi kinerja pegawai pada Bidang Sumber Daya Air Dinas Pekerjaan Umum dan Penataan Ruang Provinsi Bengkulu adalah faktor kualitas pekerjaan pegawai Bidang Sumber Daya Air Dinas Pekerjaan Umum dan Penataan Ruang Provinsi Bengkulu dengan jumlah nilai dari persepsi responden 884 dengan kriteria setuju.

Rata-rata dari jawaban responden dari keseluruhan faktor adalah 862,86 dalam kriteria setuju, artinya responden rata-rata menyetujui bahwa keseluruhan faktor yang diajukan dapat mempengaruhi kinerja pegawai pada Bidang Sumber Daya Air Dinas Pekerjaan Umum dan Penataan Ruang Provinsi Bengkulu. Faktor yang paling rendah mempengaruhi kinerja pegawai pada Bidang Sumber Daya Air Dinas Pekerjaan Umum dan Penataan Ruang Provinsi Bengkulu adalah faktor inovasi pegawai Bidang Sumber Daya Air Dinas Pekerjaan Umum dan Penataan Ruang Provinsi Bengkulu dengan jumlah nilai dari persepsi responden 829 dengan kriteria setuju.
\end{abstract}

\begin{abstract}
Nia Indriasari, Oni Yulianti, Herawati; Study aims to determine the dominant factors affecting the employees' performance in the division of water resources at Dinas Pekerjaan Umum dan Penataan Ruang of Bengkulu Province. The most dominant factor / the highest affects the employees' performance in the division of water resources at Dinas Pekerjaan Umum dan Penataan Ruang of Bengkulu Province is the quality factor of employment the division of water resources at Dinas Pekerjaan Umum dan Penataan Ruang of Bengkulu Province with the total value of the respondent's perception 884 with agreed criteria.The average of the respondents' answers to the overall factor is 862.86 in the agreed criteria, meaning that the average respondent agrees that the overall factor proposed can affect the employees' performance in the division of water resources at Dinas Pekerjaan Umum dan Penataan Ruang of Bengkulu Province.

The lowest factor affects the employees' performance in the division of water resources at Dinas Pekerjaan Umum dan Penataan Ruang of Bengkulu Province is an innovation factor of the employees in the division of water resources at Dinas Pekerjaan Umum dan Penataan Ruang of Bengkulu Province with the number of values from the perception of respondents 829 with the criteria agreed.
\end{abstract}

Key Words: Quality of work, quantity of work, job knowledge, teamwork, creativity, innovation, initiative

\section{LATAR BELAKANG}

Sumber daya manusia yang bekerja dalam organisasi hendaknya memiliki kemampuan dalam meningkatkan kualitas kinerjanya, dan kualitas kinerja tersebut dapat ditingkatkan dengan berbagai faktor yang melatar belakanginya, sehingga setiap pegawai yang bekerja dalam organisasi harus benarbenar mampu menjalankan faktor-faktor yang dapat membantu pegawai mendapatkan predikat bekerja dengan kualitas kinerja yang baik. Artinya ketika sebuah organisasi tidak memiliki sumber daya manusia untuk mengerakkan kegiatannya, maka organisasi tidak akan dapat berjalan dengan baik. Mengetahui betapa pentingnya sumber daya manusia yang berperan membawa segala potensi sumber daya dalam organisasi untuk meraih keberhasilan baik itu keberhasilan pribadi sumber daya manusia itu sendiri maupun bagi organisasi, maka organisasi harus benar-benar mampu merekrut dan memberdayakan sumber daya dengan kualifikasi kerja yang baik sehingga dapat membawa kinerja yang optimal demi pencapaian tujuan organisasi.

Pengembangan sumber daya manusia pada intinya merupakan upaya organisasi untuk membangun kualitas pegawai agar mampu melaksanakan seluruh pekerjaan yang menjadi tanggung jawabnya sesuai dengan tugas pokok dan fungsi yang ada dalam organisasi dan pengembangan pegawai 
agar memiliki kualifikasi yang baik adalah salah satu cara untuk memecahkan permasalahan kerja yang mengakibatkan turunnya kualitas kinerja pegawai dalam organisasi.

Kinerja pegawai tergantung dari baik buruknya apa yang dilakukan oleh pegawai itu sendiri. Hal yang dapat menjadi ancaman adalah apabila kinerja tidak dapat dilaksanakan sesuai dengan tujuan organisasi dan ketika tujuan yang diharapkan tidak dapat dicapai maka hal ini akan mengakibatkan masalah baru baik itu terhadap pemerintah maupun masyarakat.

Salah satu organisasi yang membutuhkan kualitas kinerja yang baik dari pegawainya adalah Bidang Sumber Daya Air Dinas Pekerjaan Umum Dan Penataan Ruang Provinsi Bengkulu. Dinas Pekerjaan Umum dan Penataan Ruang Provinsi Bengkulu merupakan organisasi pemerintahan yang bergerak dibidang pembangunan dan penataan di Provinsi Bengkulu, sehingga hasil kerja bergantung pada kualitas kinerja yang diberikan oleh setiap pegawai yang bekerja didalamnya. Hal ini dikarenakan pengaruh dinamika global disadari maupun tidak disadari, pada suatu saat nanti akan sampai kepada setiap organisasi dimanapun berada termasuk Bidang Sumber Daya Air Dinas Pekerjaan Umum Dan Penataan Ruang Provinsi Bengkulu.

Diketahui bahwa terdapat permasalahan yang terjadi dalam Bidang Sumber Daya Air Dinas Pekerjaan Umum Dan Penataan Ruang Provinsi Bengkulu akibat dari masih belum meratanya kinerja yang dihasilkan oleh masing-masing pegawai yang bekerja. Bidang Sumber Daya Air Dinas Pekerjaan Umum Dan Penataan Ruang Provinsi Bengkulu merupakan bagian Pegawai Bidang Sumber Daya Air Dinas Pekerjaan Umum Dan Penataan Ruang Provinsi Bengkulu merupakan bagian dari Dinas Pekerjaan Umum dan Penataan Ruang Provinsi Bengkulu mempunyai tugas mengumpulkan bahan, koordinasi dan melaksanakan pengaturan, pembinaan, bantuan teknis, pembangunan, rehabilitasi dan pemanfaatan sumber daya air.

Menurut Moorhead dan Chung/Megginson dalam Sugiono (2009:12) terdapat indikatorindikator yang mempengaruhi kinerja pegawai yaitu kualitas pekerjaan, kuantitas pekerjaan, pengetahuan pekerjaan, kerjasama tim, kreatifitas, inovasi, dan inisiatif.

Berdasarkan prasurvei yang dilakukan bahwa indikasi yang berkaitan dengan masalah kinerja Pegawai Negeri Sipil dari indikator kualitas pekerjaan bahwa adanya pegawai yang dalam mengerjakan pekerjaan yang diterimanya terlihat masih ada yang belum teliti, kurang rapi dalam bekerja dalam ini tentunya harus diatasi supaya mereka lebih terampil dan cakap dalam bekerja. Sedangkan dari segi kuantitas pekerjaan masih terdapat pekerjaan yang belum terselesaikan dengan tepat waktu, tentunya kendala ini juga harus diatasi sebab jika pekerjaan lama terlambat maka pekerjaan yang barupun akan tertunda juga penyelesaiannya karena harus menunggu penyelesaian pekerjaan yang terlambat tersebut.

Dari segi pengetahuan pekerjaan, masih dijumpai bahwa pegawai yang diberikan tugas masih kurang memahami hal-hal yang berkaitan dengan tugas yang mereka lakukan. Sedangkan dari indikator kerja sama tim masih dijumpai pegawai yang kurang dapat berkoordinasi dengan rekan kerjanya, tentunya hal ini akan menghambat penyelesaian suatu pekerjaan dengan cepat dan tepat. Selain itu juga kurang kreatifitas dan inisiatifnya dalam bekerja.

\section{Landasan Teori}

\section{Manajemen Sumber Daya Manusia}

Dari keseluruhan sumber daya yang tersedia dalam suatu organisasi, baik organisasi publik maupun swasta, sumber daya manusialah yang paling penting dan sangat menentukan. Sumber daya manusia merupakan satu-satunya sumber daya yang memiliki akal, perasaan, keinginan, kemampuan, ketrampilan, pengetahuan, dorongan, daya dan karya. Sumber daya manusia tidak dapat diperlakukan seperti sumbar daya lainnya, sebab satu-satunya sumber daya yang memiliki ratio, rasa, dan karsa. Semua potensi sumber daya manusia tersebut sangat berpengaruh terhadap upaya organisasi dalam pencapaian tujuannya. Betapapun majunya teknologi, berkembangnya informasi, tersedianya modal dan memadainya bahan, namun jika tanpa sumber daya manusia maka akan sulit bagi organisasi untuk mencapai tujuannya. Betapapun bagusnya perumusan tujuan dan rencana organisasi, agaknya hanya akan sia-sia belaka jika unsur sumber daya manusianya tidak diperhatikan, apalagi kalau di telantarkan.

Menurut Dessler dalam Sutrisno (2009:4) manajemen sumber daya manusia dapat didefinisikan sebagai suatu kebijakan dan praktik yang dibutuhkan seseorang yang menjalankan aspek "orang" atau sumber daya manusia dari posisi seorang manajemen, meliputi perekrutan, penyaringan, pelatihan, pengimbalan, dan penilaian sedangkan menurut Tulus dalam Sulistyani (2009:13) MSDM adalah perencanaan, pengorganisasian, pengarahan dan pengawasan atas pengadaan, pengembangan pemberian konpensasi, pengintegrasian, pemeliharaan dan pemutusan hubungan tenaga kerja dengan maksud untuk membantu mencapai tujuan organisasi, individu masyarakat.

Berbeda dengan sejumlah pendapat di atas, Mary Parker Follet dalam Sulistiyani (2009:14) mengungkapkan bahwa MSDM dapat diartikan sebagai seni untuk menyelesaikan pekerjaan melalui 
orang Iain. Definisi ini mengandung pengertian bahwa para manajer (pimpinan) mencapai tujuan-tujuan organisasi melalui pengaturan orang-orang lain untuk melaksanakan berbagai urusan kepegawaian yang diperlukan dengan memperlakukan bawahan secara individual/ kelompok. Sedang lingkupnya meliputi: penarikan, seleksi, pengembangan, pemeliharaan SDM untuk mencapai tujuan individu/organisasi.

MSDM sebenamya merupakan suatu gerakan pengakuan terhadap pentingnya unsur manusia sebagai sumber daya yang cukup potensial, yang perlu dikembangkan sedemikian rupa sehingga mampu memberikan kontribusi yang maksimal bagi organisasi dan bagi pengembangan dirinya Istilah MSDM kini semakin populer, menggantikan istilah personalia. Meskipun demikian istilah personalia ini masih tetap dipergunakan dalam banyak organisasi untuk memahami departemen yang menangani kegiatan-kegiatan seperti rekrutmen, seleksi, pemberian kompensasi dan pelatihan pegawai.

Manajemen sumber daya manusia merupakan bagian dari manajemen keorganisasian yang memfokuskan diri pada unsur sumber daya manusia. Manajemen sumber daya manusia mempunyai tugas untuk mengelola unsur manusia secara baik agar diperoleh tenaga kerja yang puas akan pekerjaannya. Menurut Umar dalam Sutrisno (2009:5) dalam tugasnya manajemen sumber daya manusia dapat dikelompokkan atas tiga fungsi, yaitu :

1. Fungsi manajerial: perencanaan, pengorganisasian, pengarahan dan pengendalian.

2. Fungsi operasional pengadaan, pengembangan, kompensasi, pengintegrasian, pemeliharaan, dan pemutusan hubungan kerja;

3. Fungsi ketiga adalah kedudukan manajemen sumber daya manusia dalam pencapaian tujuan organisasi organisasi secara terpadu.

Manajemen sumber daya manusia mengatur dan menempatkan program kepegawaian yang mencakup masalah-masalah sebagai berikut :

a. Menempatkan jumlah, kualitas, dan penempatan tenaga kerja yang efektif sesuai dengan kebutuhan organisasi berdasarkan Job Deskription, Job Spesification.

b. Menetapkan penarikan, seleksi, dan penempatan pegawai berdasarkan atas the right man on the right place and right man on the right job.

c. Menempatkan program kesejahteraan, pengembangan, promosi, dan pemberhentian

d. Melaksanakan pendidikan, latihan, dan penilaian prestasi pegawai

e. Mengatur mutasi pegawai baik vertikal maupun horizontal.

Peranan manajemen sumber daya manusia bagi kesuksesan suatu organisasi sangat menentukan, kendatipun tidak dapat dipungkiri bahwa sekarang ini dunia berada pada era globalisasi yang serba modem. Tenaga manusia sudah banyak yang telah digantikan oleh peralatan yang serba canggih seperti : mesin-mesin otomatis, komputer, dan lain-lain yang bergerak secara efektif dan efisien.

\section{Kinerja.}

Kinerja adalah hasil atau tingkat keberhasilan seseorang secara keseluruhan selama periode tertentu dalam melaksanakan tugas dibandingkan dengan berbagai kemungkinan, seperti standar hasil kerja, target atau sasaran atau kriteria yang telah ditentukan terlebih dahulu telah disepakati bersama (Rivai dan Basri, 2005:50).

Mangkunegara (2007:22) mengatakan bahwa kinerja merupakan prestasi kerja, yaitu perbandingan antara hasil kerja dengan standar yang ditetapkan sedangkan Dessler (2010:41) berpandapat bahwa kinerja adalah hasil kerja baik secara kualitas maupun kuantitas yang dicapai oleh seseorang dalam melaksanakan tugas sesuai tanggung jawab yang diberikan.

Sinambela (2012:136), mengemukakan bahwa kinerja pegawai didefinisikan sebagai kemampuan pegawai dalam melakukan sesuatu keahlian tertentu. Kinerja pegawai sangatlah perlu sebab dengan kinerja ini akan diketahui seberapa jauh kemampuan pegawai dalam melaksanakan tugas yang dibebankan kepadanya. Untuk itu diperlukan penentuan kriteria yang jelas dan terukur serta ditetapkan secara bersama-sama yang dijadikan sebagai acuan, jika disimak berdasarkan etimologinya, kinerja berasal dari kata performance. Performance berasal dari kata to perform yang mempunyai beberapa masukan (entries): (1) memasukkan, menjalankan, melaksanakan; (2) memenuhi atau menjalankan kewajiban suatu nazar; (3) menggambarkan suatu karakter dalam suatu permainan; (4) menggambarkannya dengan suara atau alat musik; (5) melaksanakan atau menyempumakan tanggungjawab; (6) melakukan suatu kegiatan dalam suatu permainan; (7) memainkan musik; (8) melakukan sesuatu yang diharapkan oleh seseorang atau mesin. Sedangkan Pasolong (2010:176) kinerja merupakan hasil kerja secara kualitas dan kuantitas yang dicapai oleh seseorang dalam melaksanakan fungsinya sesuai dengan tanggung jawab yang diberikan kepadanya.

Berbagai pendapat diatas dapat menggambarkan bahwa kinerja pegawai dan kinerja organisasi memiliki keterkaitan yang sangat erat, tercapainya tujuan organisasi tidak bisa dilepaskan dari sumber daya yang dimiliki oleh organisasi yang digerakan atau dijalankan pegawai yang berperan aktif sebagai 
pelaku dalam upaya mencapai tujuan organisasi. Jadi dapat disimpulkan bahwa kinerja pegawai adalah penilaian hasil kerja seseorang dalam suatu organisasi sesuai dengan tugas dan tanggungjawabnya dalam rangka mencapai tujuan organisasi

\section{Faktor Yang Mempengaruhi Kinerja}

Menurut Wexley dalam Sinambela (2012:10) kinerja merupakan implementasi dari teori keseimbangan, yang mengatakan bahwa seseorang akan menunjukkan prestasi yang optimal bila ia mendapatkan manfaat (benefit) dan terdapat adanya rangsangan (inducement) dalam pekerjaannya secara adil dan masuk akal (reasonable). Teori keseimbangan di atas memperlihatkan bahwa kinerja yang optimal akan dapat dicapai jika terdapat rasa keadilan yang dirasakan pegawai. Berbagai indikator yang dapat mengakibatkan rasa keadilan tersebut menurut teori ini antara Iain adalah manfaat yang berarti bahwa seorang pegawai dalam nnelaksanakan tugas-tugasnya dapat merasakan manfaatnya. Selanjutnya seorang pegawai juga harusnya memperoleh rangsangan dari berbagai pihak terkait dalam bentuk pemberian motivasi, sehingga mereka dapat terpacu untuk melakukan tugas-tugasnya; dan pekerjaan yang dilakukan haruslah adil dan masuk akal, dalam artian bahwa di antara sesama pegawai haruslah terdapat keadilan pembagian tugas dan insentif yang diperoleh.

Menurut Haynes dalam Sinambela (2012:8) kinerja dapat dioptimumkan melalui penetapan deskripsi jabatan yang jelas dan terukur bagi setiap pejabat (pegawai), sehingga mereka mengerti apa fungsi dan tanggung jawabnya. Dalam hal ini deskripsi jabatan yang baik akan dapat menjadi landasan untuk:

1. Penentuan gaji.

Hasil deskripsi jabatan akan berfungsi menjadi dasar untuk perbandingan pekerjaan dalam suatu organisasi dan dapat dijadikan sebagai acuan pemberian gaji yang adil bagi pegawai dan sebagai data pembanding dalam persaingan dalam perusahaan.

2. Seleksi pegawai.

Deskripsi jabatan sangat dibutuhkan dalam penerimaan, seleksi dan penempatan pegawai. Selain itu juga merupakan sumber untuk pengembangan spesifikasi pekerjaan yang dapat menjelaskan tingkat kualifikasi yang dimiliki oleh seorang pelamar dalam jabatan tertentu.

3. Orientasi.

Deskripsi jabatan dapat mengenalkan tugas-tugas pekerjaan yang baru kepada pegawai dengan cepat dan efisien.

4. Penilaian kinerja.

Deskripsi jabatan menunjukkan perbandingan bagaimana seseorang pegawai memenuhi tugasnya dan bagaimana tugas itu seharusnya dipenuhi.

5. Pelatihan dan pengembangan.

Deskripsi jabatan akan memberikan analisis yang akurat mengenai pelatihan yang diberikan dan perkembangan untuk membantu pengembangan karir.

6. Uraian dan perencanaan organisasi.

Perkembangan awal dari deskripsi jabatan menunjukkan dimana kelebihan dan kekurangan dalam pertanggung jawaban. Dalam hal ini deskripsi jabatan akan menyeimbangkan tugas dan tanggung jawab.

7. Uraian tanggung jawab.

Deskripsi jabatan akan membantu individu untuk memahami berbagai tugas dan tanggung jawab yang diberikan kepadanya.

Terdapat beberapa pendapat yang mengenai faktor-faktor yang mempengaruhi kinerja pegawai.

Menurut Moorhead dan Chung/Megginson dalam Sugiono (2009:12) kinerja pegawai dipengaruhi oleh beberapa faktor, yaitu ;

a. Kualitas Pekerjaan (Quality of Work) :

Merupakan tingkat baik atau buruknya sesuatu pekerjaan yang diterima bagi seorang pegawai yang dapat dilihat dari segi ketelitian dan kerapihan kerja, keterampilan dan kecakapan.

b. Kuantitas Pekerjaan (Quantity of Work) :

Merupakan seberapa besarnya beban kerja atau sejumlah pekerjaan yang harus diselesaikan oleh seorang pegawai. Diukur dari kemampuan secara kuantitatif didalam mencapai target atau hasil kerja atas pekerjaan-pekerjaan baru.

c. Pengetahuan Pekerjaan (Job Knowledge)

Merupakan proses penempatan seorang pegawai yang sesuai dengan background pendidikan atau keahlian dalam suatu pekerjaan. Hal ini ditinjau dari kemampuan pegawai dalam memahami hal-hal yang berkaitan dengan tugas yang mereka lakukan.

1. Kerjasama Tim (Teamwork) : 
Melihat bagaimana seorang pegawai bekerja dengan orang lain dalam menyelesaikan suatu pekerjaan. Kerjasama tidak hanya sebatas secara vertikal ataupun kerjasama antar pegawai, tetapi kerjasama secara horizontal merupakan faktor penting dalam suatu kehidupan organisasi yaitu dimana antar pimpinan organisasi dengan para pegawainya terjalin suatu hubungan yang kondusif dan timbal balik yang saling menguntungkan.

2. Kreatifitas (Creativity) :

Merupakan kemampuan seorang pegawai dalam menyelesaikan pekerjaannya dengan cara atau inisiatif sendiri yang dianggap mampu secara efektif dan efisien serta mampu menciptakan perubahan-perubahan baru guna perbaikan dan kemajuan organisasi

3. Inovasi (Inovation) :

Kemampuan menciptakan perubahan-perubahan baru guna perbaikan dan kemajuan organisasi.Hal ini ditinjau dari ide-ide cemerlang dalam mengatasi permasalahan organisasi.

4. Inisiatif (initiative) :

Melingkupi beberapa aspek seperti kemampuan untuk mengambil langkah yang tepat dalam menghadapi kesulitan, kemampuan untuk melakukan sesuatu pekerjaan tanpa bantuan, kemampuan untuk mengambil tahapan pertama dalam kegiatan.

Berdasarkan tinggi rendahnya kinerja, Fuad (2000:62) mengklasifikasikan kinerja karyawan dapat menjadi tiga, yaitu:

1. Kinerja tinggi (hight performer)

Bawahan yang karena oleh upayanya sendiri senantiasa dapat melampaui tolok ukur kinerja yang telah ditetapkan baginya oleh manjemen, Walaupun dalam kondisi yang sulit sekalipun;

2. Kinerja sedang (statinfactory)

Bawahan yang dapat mencapai kinerja yang diharapkan aapabila kondisi yang dihadapi normal, atau gagal mencapai tingkat kinerja yang ditetapkan karena faktor ekstemal di luar jangkauan bawahan tersebut;

3. Kinerja rendah (low performer)

Bawahan yang dikarenakan oleh usahanya sendiri, yang senantiasa tidak pernah berhasil dalam mencapai standar kelja diinginkan 'oagi organisasi.

Menurut Pasolong (2010:186), faktor-faktor yang mempengaruhi kinerja pegawai adalah sebagai

berikut :

a. Kemampuan, yaitu kemampuan dalam suatu bidang yang dipengaruhi oleh bakat, intelegensi (kecerdasan) yang mencukupi dan minat.

b. Kemauan, yaitu kesediaan untuk mengeluarkan tingkat upaya yang tinggi untuk tujuan organisasi.

c. Energi, yaitu sumber kekuatan dari dalam diri seseorang. Dengan adanya energi, seseorang mampu merespon dan bereaksi terhadap apapun yang dibutuhkan, tanpa berpikir panjang atau perhatian secara sadar sehingga ketajaman mental serta konsentrasi dalam mengelola pekerjaan menjadi lebih tinggi.

d. Teknologi, yaitu penerapan pengetahuan yang ada untuk mepermudah dalam melakukan pekerjaan.

e. Kompensasi, yaitu sesuatu yang diterima oleh pegawai sebagai balas jasa atas kinerja dan bermanfaat baginya.

f. Kejelasan tujuan, yaitu tujuan yang harus dicapai oleh pegawai. Tujuan ini harus jelas agar pekerjaan yang dilakukan oleh pegawai dapat terarah dan berjalan lebih efektif dan efisien.

g. Keamanan, yaitu kebutuhan manusia yang fundamental, karena pada umumnya seseorang yang merasa aman dalam melakukan pekerjaannya, akan berpengaruh kepada kinerjanya.

Dalam memberikan batasan untuk mengukur kinerja pegawai maka T.R. Michel dalam Rizky

(2001:15) memberikan penjelasan mengenai indikator kinerja yang meliputi :

a. Kualitas pekerjaan (Quality of work), yaitu kualitas pekerjaan yang dihasilkan dapat memuaskan organisasi, sehingga hal ini dijadikan sebagai standar kerja.

b. Komunikasi (Communication), yaitu kemampuan pegawai dalam berkomunikasi dengan baik.

c. Kecepatan (Promptness), yaitu kecepatan bekerja yang diukur oleh tingkat waktu, sehingga pegawai dituntut untuk bekerja cepat dalam mencapai kepuasan dan peningkatan kerja.

d. Kemampuan (Capability), yaitu kemampuan dalam melakukan pekerjaan semaksimal mungkin.

e. Inisiatif (Intiative), yaitu setiap pegawai mampu menyelesaikan masalah pekerjaannya sendiri agar tidak terjadi kemandulan dalam pekerjaan.

Pengukuran kinerja pegawai dapat dilakukan dengan menggunakan instrumen pengukuran kinerja yang dikembangkan oleh Zeithaml, Parasuraman dan Beny (dalam Ratminto dan Winarsih, 2007:182), sebagai berikut:

a. Ketampakan fisik (tangible). 
b. Reliabilitas (reabilily).

c. Responsivitas (responsiveness).

d. Kompetensi (competence).

e. Kesopanan (courtesy).

f. Kreadibilitas (credibility).

g. Keamanan (security).

h. Akses (access).

i. Komunikasi (communication).

j. Pengertian (understanding the customer).

\section{Kerangka Analisis}

Faktor-faktor yang mempengaruhi

kinerja pegawai :

a. Kualitas pekerjaan (Quality of Work).

b. Kuantitas pekerjaan (Quantity of Work)

c. Pengetahuan pekerjaan (Job Knowledge).

d. Kerjasama tim (Teamwork).

e. Kreatifitas (Creativity)

f. Inovasi (Inovation).

g. Inisiatif (initiative)
Faktor yang paling

dominan

mempengaruhi

Kinerja Pegawai

\section{Hasil Penelitian Dan Pembahasan} ditabulasikan.

Penulis menggunakan metode rating scale dalam menganalisis, setelah data yang diperoleh

Bidang Sumber Daya Air Dinas Pekerjaan Umum dan Penataan Ruang Provinsi Bengkulu membutuhkan pegawai sebagai pelaksanana setiap pekerjaan yang harus dilakukan demi pencapaian tujuan yang signifikan, maka dari itu pegawai dituntut untuk memberikan kualitas kinerja yang maksimal agar pencapaian tujuan tersebut dapat terlaksana, pegawai dituntut untuk memiliki kekuatan dalam kualitas pekerjaannya, kuantitas pekerjaan, pengetahuan pekerjaan, kerja sama tim, kreatifitas, inovasi serta inisiatif yang tinggi.

Dari hasil penelitian yang dilakukan pada pegawai Bidang Sumber Daya Air Dinas Pekerjaan Umum dan Penataan Ruang Provinsi Bengkulu yang peroleh dari hasil jawaban responden mengenai isi kuesioner yang terdiri dari pernyataan-pernyataan yang mewakili faktor-faktor kualitas pekerjaan, kuantitas pekerjaan, pengetahuan pekerjaan, kerja sama tim, kreatifitas, inovasi dan inisiatif.

Dari keseluruhan faktor yang diajukan sebagai faktor yang mempengaruhi kinerja pegawai pada Bidang Sumber Daya Air Dinas Pekerjaan Umum dan Penataan Ruang Provinsi Bengkulu memperoleh kriteria jawaban setuju (S), yang artinya pegawai menyetujui dengan ajuan penelitian ini yang mengajukan terdapat adanya tujuh faktor yang mempengaruhi kinerja pegawai pada Bidang Sumber Daya Air Dinas Pekerjaan Umum dan Penataan Ruang Provinsi Bengkulu

Berdasarkan hasil penelitian dan pembahasan tentang faktor-faktor yang mempengaruhi kinerja pegawai pada Bidang Sumber Daya Air Dinas Pekerjaan Umum dan Penataan Ruang Provinsi Bengkulu, maka diketahui faktor yang menjadi faktor paling dominan dalam mempengaruhi kinerja pegawai. Agar dapat mengetahui faktor mana saja yang paling dominan yang dapat mempengaruhi kinerja pegawai pada Bidang Sumber Daya Air Dinas Pekerjaan Umum dan Penataan Ruang Provinsi Bengkulu maka peneliti membuat tabel rata-rata hasil jawaban responden sebagai berikut:

Tabel 12. Skor rata-rata variabel kinerja pegawai

\begin{tabular}{|c|l|c|c|}
\hline No & \multicolumn{1}{|c|}{ Indikator kinerja pegawai } & Jumlah & Keterangan \\
\hline 1 & Kualitas pekerjaan & 884 & Setuju \\
\hline 2 & Kuantitas pekerjaan & 875 & Setuju \\
\hline 3 & Pengetahuan pekerjaan & 880 & Setuju \\
\hline
\end{tabular}




\begin{tabular}{|c|l|c|c|}
\hline 4 & Kerja sama tim & 860 & Setuju \\
\hline 5 & Kreatifitas & 842 & Setuju \\
\hline 6 & Inovasi & 829 & Setuju \\
\hline 7 & Inisiatif & 870 & Setuju \\
\hline & Jumlah Skor & 6040 & \\
\hline & Rata-rata 6040/7 & 862,86 & Setuju \\
\hline
\end{tabular}

Sumber : Tabel 5-12, 2017

Keterangan :
a. $219-394,2=$ STS
b. $394,2-569,4=$ TS
c. $569,4-744,6=\mathrm{CS}$
d. $744,6-919,8=\mathrm{S}$
e. $919,8-1.095=\mathrm{SS}$

Dari tabel 12 diketahui bahwa faktor yang paling dominan mempengaruhi kinerja pegawai pada Bidang Sumber Daya Air Dinas Pekerjaan Umum dan Penataan Ruang Provinsi Bengkulu adalah faktor kualitas pekerjaan dengan jumlah nilai skor dari persepsi responden 884 dengan kriteria setuju.

Rata-rata dari jawaban responden dari keseluruhan faktor adalah 862,86 dalam kriteria setuju, artinya responden rata-rata menyetujui bahwa keseluruhan faktor yang diajukan dapat mempengaruhi kinerja pegawai pada Bidang Sumber Daya Air Dinas Pekerjaan Umum dan Penataan Ruang Provinsi Bengkulu. 13 berikut :

Untuk melihat lebih jelas akan diurutkan dengan menggunakan rating scale seperti pada tabel

Tabel 13. Ranking variabel kinerja pegawai

\begin{tabular}{|c|l|c|}
\hline Ranking & \multicolumn{1}{|c|}{$\begin{array}{c}\text { Faktor-Faktor yang mempengaruhi } \\
\text { kinerja pegawai }\end{array}$} & Skor Rata-rata \\
\hline I & Kualitas pekerjaan & 884 \\
\hline II & Pengetahuan pekerjaan & 880 \\
\hline III & Kuantitas pekerjaan & 875 \\
\hline IV & Inisiatif & 870 \\
\hline V & Kerja sama tim & 860 \\
\hline VI & Kreatifitas & 842 \\
\hline VII & Inovasi & 829 \\
\hline
\end{tabular}

Sumber : Tabel 13, diolah, 2017

Dari tabel 13 menunjukkan bahwa faktor kualitas pekerjaan yang diberikan oleh pegawai Bidang Sumber Daya Air Dinas Pekerjaan Umum dan Penataan Ruang Provinsi Bengkulu adalah faktor yang paling dominan dalam mempengaruhi kinerja pegawai pada Bidang Sumber Daya Air Dinas Pekerjaan Umum dan Penataan Ruang Provinsi Bengkulu.

Kinerja pegawai merupakan ujung tombak dari berjalan atau tudaknya sebuah organisasi, dan hal inilah yang terjadi pada Bidang Sumber Daya Air Dinas Pekerjaan Umum dan Penataan Ruang Provinsi Bengkulu, dengan tidak adanya kinerja yang baik yang diperoleh oleh pegawai untuk Bidang Sumber Daya Air Dinas Pekerjaan Umum dan Penataan Ruang Provinsi Bengkulu maka Bidang Sumber Daya Air Dinas Pekerjaan Umum dan Penataan Ruang Provinsi Bengkulu tidak akan dapat mencapai tujuannya.

Pada Bidang Sumber Daya Air Dinas Pekerjaan Umum dan Penataan Ruang Provinsi Bengkulu pegawai merasakan bahwa pentingnya kinerja merupakan hal yang tidak bisa dielakkan, terlebih meningkatkan kinerja dengan baik merupakan sebuah kewajiban yang harus dilaksanakan oleh pegawai Bidang Sumber Daya Air Dinas Pekerjaan Umum dan Penataan Ruang Provinsi Bengkulu agar Bidang Sumber Daya Air Dinas Pekerjaan Umum dan Penataan Ruang Provinsi Bengkulu dapat menjalankan tujuannya sesuai yang ditugaskan oleh pemerintah untuk Provinsi Bengkulu.

Diketahui bahwa pegawai pada Bidang Sumber Daya Air Dinas Pekerjaan Umum dan Penataan Ruang Provinsi Bengkulu memiliki kualitas kerja yang baik hal ini didasari oleh perolehan hasil kerja pegawai yang rapi dan benar, ini dikarenakan setiap pegawai berupaya untuk melaksanakan pekerjaan dengan teliti dan cakap dalam menganalisis masalah pekerjaannya.

Dalam hal pengetahuan pekerjaan diketahui pegawai pada Bidang Sumber Daya Air Dinas Pekerjaan Umum dan Penataan Ruang Provinsi Bengkulu rata-rata sudah memiliki kemampuan dalam 
bekerja, dimana kemampuan tersebut diperoleh dari jenjang pendidikan pegawai maupun pelatihanpelatihan yang diadakan dan dengan kemampuan yang ada maka pegawai dapat melaksanakan tugasnya sesuai dengan bidang dan memahami seluk beluk pekerjaan dengan baik.

Pegawai pada Bidang Sumber Daya Air Dinas Pekerjaan Umum dan Penataan Ruang Provinsi Bengkulu juga merupakan pegawai dengan kuantitas kerja yang stabil dan sesuai dengan harapan Bidang Sumber Daya Air Dinas Pekerjaan Umum dan Penataan Ruang Provinsi Bengkulu, pegawai berupaya untuk melaksanakan seluruh pekerjaan yang diberikan sesuai dengan target yang telah ditentukan dan tentunya pegawai juga mampu dan bersedia untuk diberikan tugas tambahan sebagai kewajibannya selaku pegawai yang bekerja pada Bidang Sumber Daya Air Dinas Pekerjaan Umum dan Penataan Ruang Provinsi Bengkulu.

Inisiatif kerja pegawai Bidang Sumber Daya Air Dinas Pekerjaan Umum dan Penataan Ruang Provinsi Bengkulu diketahui sudah dalam keadaan baik, karena pegawai memiliki kesadaran yang tinggi akan pelaksanaan tugas yang diberikan kepada pegawai dalam Bidang Sumber Daya Air Dinas Pekerjaan Umum dan Penataan Ruang Provinsi Bengkulu, sehingga kualitas dan kuantitas pekerjaan dalam keadaan baik, inisiatif pegawai dapat terlihat dari adanya rasa tidak keberatan ketika pegawai diberikan tugas, dan tugaspun dilaksanakan baik dengan atau tanpa bantuan yang signifikan dari rekan maupun pimpinannya, pegawai juga mampu mengambil langkah yang tepat ketika berada dalam masalah, sehingga meminimalisir kesalahan dalam bekerja.

Kerja sama tim merupakan hal yang harus dilakukan disetiap organisasi begitupula dengan Bidang Sumber Daya Air Dinas Pekerjaan Umum dan Penataan Ruang Provinsi Bengkulu, terdiri dari banyak individu yang memiliki tujuan yang sama yaitu memenuhi harapan dan tujuan organisasi, maka pegawai dituntut mampu untuk bekerja sama dengan baik antar sesama pegawai yang ada, dan menyadari hal itu maka pegwai bersedia untuk saling mendukung, dan menjalin hubungan yang kondusif sehingga pegawai yang bekerja dapat merasakan efek timbal balik yang besar dalam hal pekerjaannya.

Selanjutnya adalah kreatifitas, menjadi pegawai yang kreatif tidaklah mudah, akan tetapi pegawai pada Bidang Sumber Daya Air Dinas Pekerjaan Umum dan Penataan Ruang Provinsi Bengkulu membuktikan bahwa pegawai sudah berusaha untuk menjadi kreatif, meskipun masih ada sebagian kecil pegawai yang masih belum percaya diri atau bahkan belum mampu mengakui bahwa dirinya kreatif, diketahu bahwa pegawai pada Bidang Sumber Daya Air Dinas Pekerjaan Umum dan Penataan Ruang Provinsi Bengkulu mampu melaksanakan pekerjaan dam memecahkan masalah dengan caranya sendiri, dan pekerjaan yang dihasilkan pun merupakan pekerjaan yang efektif dan efisien sehingga kerap kali Bidang Sumber Daya Air Dinas Pekerjaan Umum dan Penataan Ruang Provinsi Bengkulu memperoleh perubahan positif dari pegawai demi perbaikan dan kemajuan Bidang Sumber Daya Air Dinas Pekerjaan Umum dan Penataan Ruang Provinsi Bengkulu.

Kreatifitas melahirkan inovasi, dan hal itu pulalah yang di peroleh oleh pegawai Bidang Sumber Daya Air Dinas Pekerjaan Umum dan Penataan Ruang Provinsi Bengkulu ketika sudah berupaya untuk menjadi kreatif dalam hal pelaksanaan pekerjaannya dalam pencapaian tujuan Bidang Sumber Daya Air Dinas Pekerjaan Umum dan Penataan Ruang Provinsi Bengkulu, meskipun mendapatkan nilai skor terendah bukan berarti pegawai Bidang Sumber Daya Air Dinas Pekerjaan Umum dan Penataan Ruang Provinsi Bengkulu tidak mampu untuk menciptakan inovasi, diketahui bahwa sebagian besar pegawai pada Bidang Sumber Daya Air Dinas Pekerjaan Umum dan Penataan Ruang Provinsi Bengkulu sudah mampu menciptakan inovasi yang mendukung jalannya pelaksanaan pekerjaan dengan baik, inovasi tersebut dapat terlihat dari bagaimana masing-masing pegawai memecahkan masalahnya masing-masing ketika melaksanakan pekerjaan, sehingga pegawai mampu mencapai target tujuan yang telah ditentukan.

\section{Kesimpulan}

Berdasarkan hasil penelitian yang dilakukan maka dapat disimpulkan sebagai berikut :

1. Faktor yang paling dominan/tertinggi mempengaruhi kinerja pegawai pada Bidang Sumber Daya Air Dinas Pekerjaan Umum dan Penataan Ruang Provinsi Bengkulu adalah faktor kualitas pekerjaan pegawai Bidang Sumber Daya Air Dinas Pekerjaan Umum dan Penataan Ruang Provinsi Bengkulu dengan jumlah nilai dari persepsi responden 884 dengan kriteria setuju.

2. Rata-rata dari jawaban responden dari keseluruhan faktor adalah 862,86 dalam kriteria setuju, artinya responden rata-rata menyetujui bahwa keseluruhan faktor yang diajukan dapat mempengaruhi kinerja pegawai pada Bidang Sumber Daya Air Dinas Pekerjaan Umum dan Penataan Ruang Provinsi Bengkulu.

3. Faktor yang paling rendah mempengaruhi kinerja pegawai pada Bidang Sumber Daya Air Dinas Pekerjaan Umum dan Penataan Ruang Provinsi Bengkulu adalah faktor inovasi pegawai Bidang 
Sumber Daya Air Dinas Pekerjaan Umum dan Penataan Ruang Provinsi Bengkulu dengan jumlah nilai dari persepsi responden 829 dengan kriteria setuju.

\section{Saran}

Dari ketujuh faktor yang mempengaruhi kinerja pegawai pada Bidang Sumber Daya Air Dinas Pekerjaan Umum dan Penataan Ruang Provinsi Bengkulu meskipun semua pernyataan mendapat persepsi setuju, akan tetapi sebaiknya pimpinan dapat terus memperhatikan dan meningkatkan dengan baik ketujuh faktor tersebut, terutama pada faktor inovasi dan kreatifitas. Dalam hal ini artinya pegawai perlu dipacu keberaniannya dalam memecahkan masalahnya masing-masing ketika melaksanakan pekerjaan, sehingga pegawai mampu mencapai target tujuan yang telah ditentukan dan juga pegawai didorong supaya kreatif dalam bekerja untuk dapat memberikan ide-ide yang baik dalam peningkatan kinerja pegawai dan organisasi.

\section{DAFTAR PUSTAKA}

Dessler, Gary. 2010. Manajemen Sumber Daya Manusia. Alih Bahasa : Eli Tanya Penyunting Bahasa: Budi Supriyanto. Indeks : Jakarta

Fuad, M. 2000. Pengantar Bisnis. Gramedia Pustaka Utama : Jakarta

Gomes, F. Cardoso. 2008. Manajemen Sumber Daya Manusia. Penerbit Andi : Yogyakarta

Luthans, Fred. 2005. Organization Behavior. Alih Bahasa : Nurdin Sobali. Erlangga: Jakarta

Mangkunegara, Anwar Prabu. 2007. Manajemen Sumber Daya Manusia Perusahaan. Bandung : PT Remaja Rosdakarya

Nurlaila, 2010. Manajemen Sumber Daya Manusia I. Lepkhair : Ternate

Pasolong, Harbani. 2010. Teori Administrasi Publik. Alfabeta : Bandung

Paulina, 2013. Hubungan Kompetensi Dengan Kinerja Pegawai Pada Satuan Kerja Penyehatan Lingkungan Permukiman (Plp) Dinas Pekerjaan Umum Provinsi Bengkulu. Skripsi Program Studi manajemn FE Unived Bengkulu

Ratminto dan Atik Septi Winarsih. 2007. Manajemen Pelayanan. Pustaka Pelajar: Yogyakarta

Rivai, Veitzhal, Ahmad Fawzi Mohd. Basri. 2005. Perfomance Appraisal : Sistem Yang Tepat Menilai Kinerja Karyawan Dan Meningkatkan Daya Saing Perusahaan. Rajawali Pers : Jakarta

Rizki, Ahmad S. 2001. Manajemen Penggajian dan Pengupahan Karyawan Perusahaan. Gramedia Utama : Jakarta

Sinambela, Poltak Lijan. 2012. Kinerja Pegawai : Teori Pengukuran Dan Implikasi. Graha Ilmu : Yogyakarta Sugiyono. 2009. Metode Penelitian Manajemen. Alfabeta : Bandung

Sugiyono. 2011. Metode Penelitian Bisnis. Alfabeta : Bandung

Sulistiyani, Ambar Teguh. 2009. Manajemen Sumber Daya Manusia. Yogyakarta : Graha Ilmu

Sutrisno, Edy. 2009. Manajemen Sumber Daya Manusia. Jakarta : Kencana 